\title{
Wstępne wyniki badań geochemicznych i mineralogicznych stref wietrzenia złoża cynku i ołowiu (obszar śląsko-krakowski)
}

\author{
Maciej Swęd ${ }^{1}$
}

\begin{abstract}
Preliminary geochemical and mineralogical results of zinc and lead weathering zones (Silesia-Cracow zinc-lead ore district). Prz. Geol., 67: 198-199; doi: 10.7306/2019.20

A b s tra ct. The study area is located within the Silesia-Cracow zinc-lead ore district. Secondary minerals were collected from the reclaimed zinc-lead underground mine in Bolestaw and from the currently operated zinc-lead underground mine Olkusz-Pomorzany. The main goal of investigations was the geochemical and mineralogical comparison of weathering zone developed within horst and tectonic graben. Semi-quantitative chemical composition was determined using the SEM-EDS method and quantitative chemical composition was determined employing the EMP microanalysis. Mineralogical investigations were performed with the XRD. The predominant zinc mineral of weathering zone located within tectonic horst is hemimorphite. No primary and secondary lead minerals were observed in this zone. In contrast, the weathering zone within tectonic graben contains secondary carbonate zinc and lead minerals. These differences could result from pervasive sulfide minerals (especially marcasite) in a graben unit, and limestones which are the main gangue rock of this zinc-lead ore.
\end{abstract}

Keywords: zinc-lead ore deposit, weathering, secondary minerals

Śląsko-krakowskie złoża cynku i ołowiu znajdują się na monoklinie śląsko-krakowskiej, w północno wschodnim obrzeżeniu Górnośląskiego Zagłębia Węglowego. Pierwotna mineralizacja siarczkowa cynku i ołowiu występuje w formie soczew i gniazd w dolomitach kruszconośnych i to one są obecnie eksploatowane. Dolomity kruszconośne zastępują epigenetycznie dolomity diagenetyczne oraz wapienie środkowego triasu, które należą do tzw. warstw olkuskich (Sass-Gustkiewicz, 1982 i in.; Górecka, 1993). Śląsko-krakowskie złoża cynku i ołowiu są zaliczane do złóż typu MVT (Missisipi Valley type) i charakteryzują się prostym składem pierwotnej mineralizacji kruszcowej, do której należą markasyt, sfaleryt oraz galena (Kucha, 2003).

W obszarze olkusko-bolesławskim strefy mineralizacji cynkowo-ołowiowej zostały rozcięte przez zręby oraz rowy tektoniczne, których powstanie wiąże się $\mathrm{z}$ ruchami orogenicznymi Karpat zewnętrznych. W strukturach tych rozwinęły się strefy wietrzenia pierwotnych kruszców cynku i ołowiu. Na obszarze zrębów płytko pod powierzchnią ziemi występują utlenione rudy cynku i ołowiu, tzw. galmany, które powstały między górną kredą a środkowym miocenem - ich eksploatacja została zaniechana (Coppola i in., 2009; Strzelska-Smakowska, 2010). Natomiast w rowach pierwotne złoże, leżące pod nadkładem skał kajpru, częściowo jury i osadów czwartorzędu, uległo miejscami przeobrażeniu chemicznemu (ryc. 1). Proces ten nastąpił przeważnie w miejscach o znacznym osłabieniu górotworu, które charakteryzują się dużą zawartością wtórnych minerałów żelaza i siarczanów. Różnice w wykształceniu składu mineralnego obu stref wietrzenia mogą być efektem odmiennych warunków fizyczno-chemicznych.

\section{CEL PRACY}

Celem pracy jest geochemiczno-mineralogiczne porównanie stref wietrzenia wykształconych na zrębach i w rowach tektonicznych olkusko-bolesławskiego obszaru śląsko-krakowskich złóż cynku i ołowiu.

\section{METODYKA BADAŃ}

Badaniom poddano trzy próbki utlenionych rud cynku i ołowiu, które pozyskano z powierzchni rekultywowanych skarp w zachodniej części Kopalni Bolesław (obszar I), oraz cztery próbki pobrane ze stref wietrzenia rud cynku i ołowiu w podziemnej Kopalni Olkusz-Pomorzany (obszar II). Z pozyskanego materiału badawczego wykonano szlify uniwersalne, które poddano obserwacjom w mikroobszarze oraz pótilościowej analizie chemicznej (SEM-EDS, Hitach S-3700N). Analizom ilościowym składu chemicznego (EMP, Cameca SX-100) poddano tylko próbki z obszaru drugiego. Badania mineralogiczne wykonano z zastosowaniem dyfraktometrii rentgenowskiej (XRD, Thermo Electron ARL X'tra).

\section{WYNIKI}

Próbki pobrane w Kopalni Bolestaw (obszar I) charakteryzuje ubóstwo pierwotnego składu mineralnego, reprezentowanego głównie przez markasyt i podrzędnie przez sfaleryt. Wtórnym minerałem cynku jest przeważnie hemimorfit. W toku badań nie oznaczono smitsonitu. W składzie chemicznym wtórnego goethytu i sporadycznie lepidokrokitu wykryto znikome ilości ołowiu. W minerałach tych oznaczono również cynk, którego zawartość znacznie przewyższa ilość ołowiu. Wtórne minerały żelaza występują w sąsiedztwie markasytów i zawierają śladowe ilości siarki. W trakcie badań próbek z Kopalni Bolesław nie wykryto wietrzeniowych minerałów ołowiu.

Do pierwotnych minerałów występujących w strefie wietrzenia rud w Kopalni Olkusz-Pomorzany (obszar II) należą: markasyt, galena oraz sfaleryt. Ślady pierwotnej mineralizacji zawierają minerały wtórne cynku i ołowiu. Analizy chemiczne tych minerałów wykazały zaniżoną zawartość cynku, ołowiu oraz siarki w stosunku do teoretycznego wzoru chemicznego. Najczęstszym wietrzeniowym minerałem ołowiu jest cerusyt, który albo tworzy się w szczelinach łupliwości galeny, albo na jej krawędziach. Niekiedy cerusyt prawie całkowicie zastępuje galenę, któ-

\footnotetext{
${ }^{1}$ Instytut Geologii, Uniwersytet im. Adama Mickiewicza, ul. Bogumiła Krygowskiego 12, 61-680 Poznań; maciej.swed@amu.edu.pl
} 


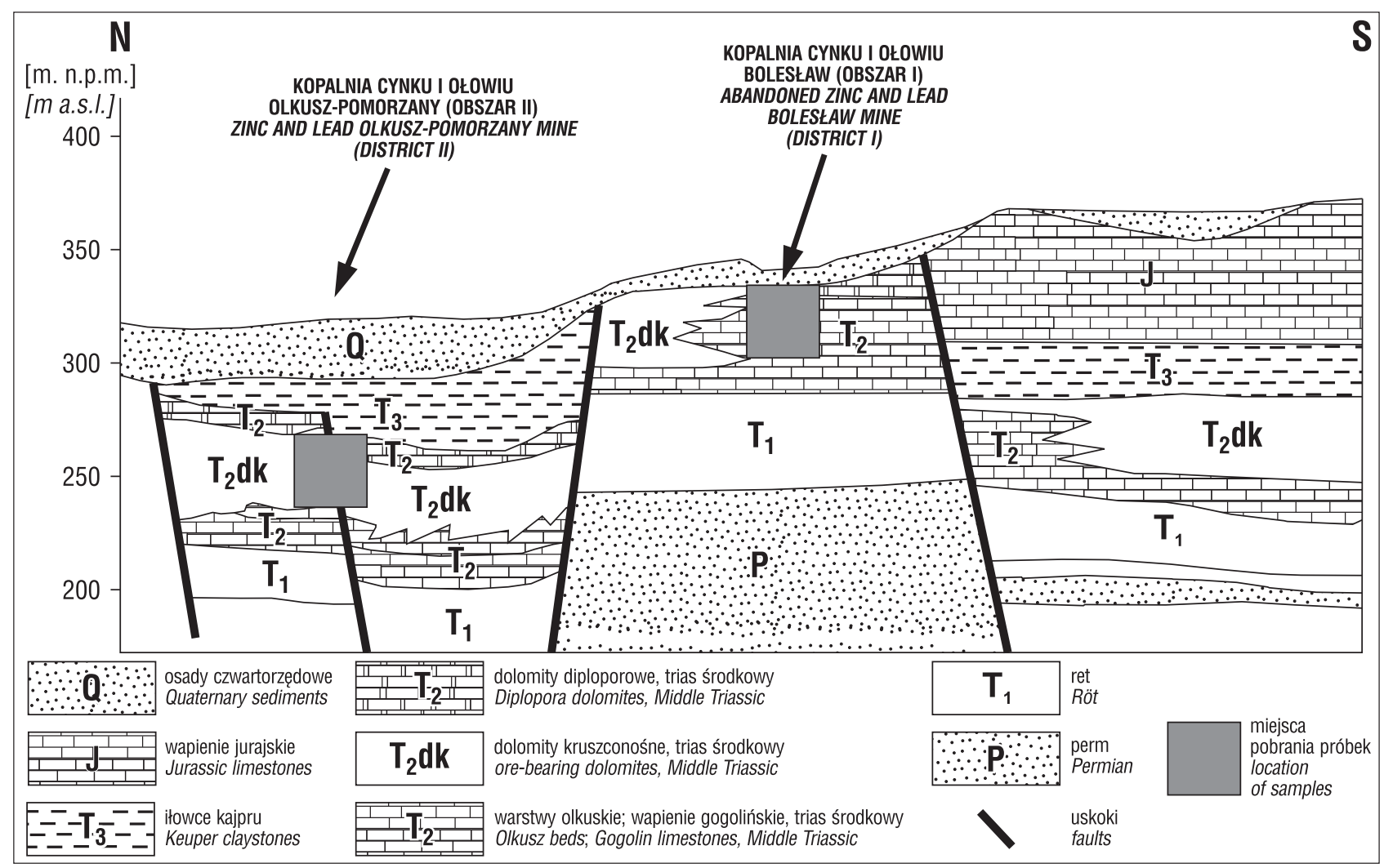

Ryc. 1. Budowa geologiczna złoża cynku i ołowiu w olkuskiej części śląsko-krakowskich złóż cynku i ołowiu (Cabała, 2009-zmieniona) Fig. 1. Geological structure of zinc and lead ore deposit in the Olkusz part of the Silesia-Cracow zinc-lead ore district (Cabała, 2009-changed)

rej ślady znajdują się w jego wnętrzu. W toku badań nie stwierdzono anglezytu. Wyniki analizy chemicznej wykazały dominujący udział cynku, który występuje głownie w postaci smitsonitu i hemimorfitu. Wysoką zawartość ołowiu stwierdzono zarówno w pierwotnej galenie, jak i wtórnym cerusycie. Charakterystyczną cechą wtórnych minerałów cynku jest ich współwystępowanie i tworzenie przerostów. Dominacja wtórnych minerałów węglanowych cynku i ołowiu w strefach wietrzenia obszaru drugiego może świadczyć o wysokim ciśnieniu cząstkowym $\mathrm{CO}_{2}$. Gaz ten jest produktem neutralizacji kwaśnych roztworów wodnych przez otaczające skały węglanowe. W efekcie tego procesu $\mathrm{w}$ strefach poddanych wietrzeniu powstają minerały siarczanowe, które powszechnie tworzą naloty na powierzchniach wyrobisk kopalnianych (Reichert, Borg, 2008; Szczerba, Sawłowicz, 2009). Wykrycie barytu wyłącznie w pobliżu markasytów może świadczyć o szybkiej neutralizacji kwaśnych roztworów powstających w wyniku wietrzenia siarczków żelaza. Współwystępowanie smitsonitu $\mathrm{z}$ hemimorfitem odzwierciedla zmianę warunków krystalizacji, w których aktywność jonów krzemu była większa niż ciśnienie czastkowe $\mathrm{CO}_{2}$. Należące do nadkładu złoża osady kajpru mogły być źródłem jonów krzemu, które występują w roztworach w formie kwasu krzemowego. Migracji krzemu w postaci rozpuszczonej sprzyja zasadowe, węglanowe środowisko.

Dominacja krzemianowych minerałów cynku w próbkach z obszaru pierwszego może świadczyć jednocześnie o mniejszym udziale skał węglanowych w strefie wietrzenia oraz o znacznie niższej zawartości minerałów siarczkowych, w szczególności markasytów. Zastanawiający jest brak galeny $\mathrm{w}$ omawianej strefie. Wynika to albo z braku pierwotnych kruszców ołowiu, albo jest efektem warunków, np. klimatycznych, sprzyjających wietrzeniu tego minerału w okresie powstawania galmanów.

\section{WNIOSKI}

1) Strefa wietrzeniowa rozwinięta w rowie tektonicznym jest wzbogacona we wtórne węglany cynku i ołowiu, rzadziej występują w niej krzemiany. Odmienna mineralizacja występuje w strefach wietrzenia wykształconych na zrębach tektonicznych, gdzie krzemiany metali stanowią dominujące wtórne fazy mineralne.

2) Większe zróżnicowanie mineralogiczne charakteryzuje strefę wietrzenia na terenie Kopalni Olkusz-Pomorzany.

3) Brak wtórnych węglanów cynku i ołowiu w strefach wietrzenia rozwiniętych w obrębie zrębów tektonicznych może wynikać z niewielkiej zawartości markasytów oraz niskiego ciśnienia czastkowego $\mathrm{CO}_{2}$.

4) Wyniki badań wskazują, że skład mineralny środowisk wietrzenia w znacznej mierze jest kształtowany przez obecność łatwo wietrzejących siarczków żelaza.

\section{LITERATURA}

CABAŁA J. 2009 - Metale ciężkie w środowisku glebowym olkuskiego rejonu eksploatacji rud cynku i ołowiu. Pr. Nauk. Uniw. Śl., 2729: 10-13. COPPOLA V., BONI M., GILG H. A., STRZELSKA-SMAKOWSKA B. 2009 - Nonsulfide zinc deposits in the Silesia-Cracow district, Southern Poland. Miner. Deposita, 44: 559-580.

GORECKA E. 1993 - Geological setting of the Silesian - Cracow Zn-Pb deposit. Geol. Quart., 37: 127-146.

KUCHA H. 2003 - Mississippi Valley Type Zn-Pb deposits of Upper Sillesia, Poland. Irish Association for Economic Geology, Dublin: 253-271. SASS-GUSTKIEWICZ M., DŻUŁYŃSKI S., RIDGE J.D. 1982 - The emplacement of zinc-lead sulfides ores in the Upper Silesian District - a contribution to the understanding of Mississippi Valley-Type Deposits. Econ. Geol., 77: 392-412.

SZCZERBA M., SAWŁOWICZ Z. 2009 - Remarks on the origin of cerussite in the Upper Silesian Zn-Pb deposit, Poland. Mineralogia, 44: 53-64. REICHERT J., BORG G. 2008 - Numerical simulation and geochemical model of supergene carbonate - hosted non-sulphide zinc deposits. Ore Geol. Rev., 33: 134-151. 